Yeshiva University, Cardozo School of Law

LARC @ Cardozo Law

Articles

Faculty

Fall 2015

\title{
Patent Markets: A Framework for Evaluation
}

Michael J. Burstein

Benjamin N. Cardozo School of Law, mburstei@yu.edu

Follow this and additional works at: https://larc.cardozo.yu.edu/faculty-articles

Part of the Law Commons

\section{Recommended Citation}

Michael J. Burstein, Patent Markets: A Framework for Evaluation, 47 Arizona State Law Journal 507 (2015).

Available at: https://larc.cardozo.yu.edu/faculty-articles/237

This Article is brought to you for free and open access by the Faculty at LARC @ Cardozo Law. It has been accepted for inclusion in Articles by an authorized administrator of LARC @ Cardozo Law. For more information, please contact larc@yu.edu. 


\title{
PATENT MARKeTS: A Framework for Evaluation
}

\author{
Michael J. Burstein*
}

\section{INTRODUCTION}

Patents have become financial assets. They are valued like securities, ${ }^{1}$ traded like stocks, ${ }^{2}$ and modeled as options. ${ }^{3}$ Our discourse about patents increasingly draws from finance. Firms whose business models depend on patent assertion explain that they are providing "liquidity" to the patent market. ${ }^{4}$ Those on the other side, which engage in collective defense, talk about using the market to mitigate "patent risk." Commentators who ordinarily take very different positions about the merits of our current patent system seem to agree that we should make patent markets more efficient. ${ }^{6}$ But neither they nor most others ask the logically prior question: should there be robust patent markets at all? This Essay provides a roadmap for answering that question. Taking seriously the analogy between patent markets and financial markets, I demonstrate that there are numerous

* Associate Professor of Law, Cardozo School of Law. I thank David Abrams, Yochai Benkler, Dan Burk, Colleen Chien, Brett Frischmann, Zachary Gubler, Mark Lemley, Robert Merges, Josh Sarnoff, Ted Sichelman, Alex Stein, Susannah Barton Tobin, Melissa Wasserman, and Chuck Yablon for helpful comments and conversations. I am also grateful to participants at the 2015 Law and Entrepreneurship Association Retreat, the 2015 NYU Tri-State Region IP Workshop, the 2014 Intellectual Property Scholars Conference, the 2014 National Business Law Scholars Conference, the 2015 PatCon: The Patent Conference, and workshops at St. John's, DePaul, and Cardozo for their feedback. Michele Aronson provided outstanding research assistance.

1. See, e.g., Maayan Perel, An Ex Ante Theory of Patent Valuation: Transforming Patent Quality into Patent Value, 14 J. HIGH TECH. L. 148, 161-70 (2014) (describing common patent valuation techniques).

2. See, e.g., Amy L. Landers, Liquid Patents, 84 DENV. U.L. REV. 199, 207-11 (2006).

3. See, e.g., Shaun Martin \& Frank Partnoy, Patents as Options, in PERSPECTIVES ON Commercializaing Innovation 303, 303 (F. Scott Kieff \& Troy A. Paredes eds., 2012); Christopher A. Cotropia, Describing Patents as Real Options, 34 J. CoRP. L. 1127, 1128 (2009).

4. Nathan Myhrvold, The Big Idea: Funding Eureka!, HARV. Bus. REV., Mar. 1, 2010, https://hbr.org/2010/03/the-big-idea-funding-eureka.

5. RPX Corp., RPX R\&D, RPX RATIONAL PATENT, http://www.rpxcorp.com/rpxservices/rpx-rd/ (last visited Nov. 14, 2015) (describing market-based approach to "rationaliz[ing] patent transactions and reducing NPE cost and risk").

6. Mark A. Lemley \& Nathan Myhrvold, How to Make a Patent Market, 36 Hofstra L. REV. 257, 258 (2007). 
circumstances in which even well-functioning patent markets will fail to promote innovation. Because "promot[ing] the [p]rogress of [s]cience and useful [a]rts," rather than achieving efficiency in the purchase and sale of patent assets, is the ultimate goal of the patent system, liquid markets cannot be a panacea. We therefore need to have a different conversation about such markets, in which we seek empirical data about when their operation is socially beneficial, and in which we consider their merits alongside other proposals for patent reform.

This Essay starts that conversation by way of a thought experiment. Imagine, if you will, a market for patents that looked roughly like the stock market or, perhaps more analogously, the real estate market. Such a market would have several characteristics. ${ }^{8}$ It would be liquid. There would be a sufficient number of willing buyers and sellers that any person wishing to transact over a patent could do so. It would be transparent, so that market participants have access to pricing and other data. And it would have relatively low transaction costs. Such a market may facilitate patent transactions at market clearing prices. But markets are also prone to pricing distortions ${ }^{9}$ and moral hazard, ${ }^{10}$ and a patent market would be no exception. Patent markets might therefore fail optimally to allocate the underlying technological asset. In this Essay, I use the thought experiment described above to assess systematically the cases for and against patent markets. I conclude that, like much in patent law, the effects of robust secondary markets are likely to vary with specific technological and business contexts. But at the very least, there are enough reasons to be skeptical of patent markets that we should proceed with caution when invoking them in policy debates about the contours of the patent system.

More importantly, patent markets are not likely to provide a complete solution to the problems associated with the modern patent system-too many patents of dubious quality and scope. Even to the extent that patent markets function as second-best mechanisms to alleviate some of the problems of patent quality, we ought not to give up on policies aimed at improving patent quality directly.

7. U.S. CONST. art. I, $\S 8, \mathrm{cl} .8$.

8. See generally FRANK J. FABOZZI ET AL., FOUNDATIONS OF FINANCIAL MARKETS AND INSTITUTIONS 5-6 (4th ed. 2010).

9. See, e.g., George A. Akerlof, The Market for "Lemons": Quality Uncertainty and the Market Mechanism, 84 Q.J. ECON. 488, 488-90 (1970).

10. See, e.g., Karl S. Okamoto, After the Bailout: Regulating Systemic Moral Hazard, 57 UCLA L. REV. 183, 189.(2009). 
The kind of robust, liquid patent markets that this: Essay describes do not yet exist. ${ }^{11}$ But they are beginning to emerge. ${ }^{12}$ Consider just a few examples of recent patent transactions. In 2011, a consortium led by Apple and Microsoft purchased over 6000 patents from Nortel Networks, a bankrupt telecommunications firm, for $\$ 4.5$ billion. ${ }^{13}$ Three years later, that consortium sold 4000 of those patents to a syndicate of thirty different companies in a deal valued at $\$ 900$ million and brokered by RPX, a patent intermediary. ${ }^{14}$ Patents appeared to drive Google's 2011 purchase of Motorola Mobility for $\$ 12.5$ billion, which included a portfolio of 24,500 pending or issued patents. ${ }^{15}$ In 2012 , Alcatel-Lucent refinanced $\$ 2.1$ billion in debt in a collateralized offering secured primarily by its patent portfolio. ${ }^{16}$ Heeding a popular call to "tap their patent portfolios for the hidden asset values and revenue streams that lie within," 17 many companies have spun off new entities whose sole purpose is to hold and monetize their patent

11. See Andrei Hagiu \& David B. Yoffie, The New Patent Intermediaries: Platforms, Defensive Aggregators, and Super-Aggregators, 27 J. ECON. PERSP. 45, $45-46$ (2013) (noting that " $[\mathrm{t}]$ here is no eBay, Amazon, New York Stock Exchange, or Kelley's Blue Book equivalent for patents," and describing patent markets as "[i]nefficient and illiquid").

12. Some refer to this emerging market as a "secondary market" for patents. See, e.g., Fed. Trade COMM'N, The Evolving IP MarketPlace: Aligning Patent Notice and REMEDIES WITH COMPETITION 58 (2011) [hereinafter FTC REPORT]. That may be something of a misnomer. In finance, secondary markets are those which arise to facilitate the purchase and sale of securities after they have been issued in the primary market. Because a patent issues to an applicant rather than to a bidder in a market, there is no primary market for patents. Nevertheless, the term may be used interchangeably to signify purchases and sales among those other than the applicant to whom the patent initially issues.

13. See M.G. Siegler, How Apple Led the High-Stakes Patent Poker Win Against Google, Sealing Ballmer's Promise, TECHCRUNCH (Jul. 9, 2011), http://techcrunch.com/2011/07/09/vesper/.

14. See Scott Graham, With Rockstar-RPX Deal, 'Tis the Season for Patent Peace, THE RECORDER (Dec. 23, 2014), http://www.rpxcorp.com/wpcontent/uploads/sites/2/2015/03/Recorder_Rockstar.pdf.

15. Mikael Ricknäs, Google Buys Motorola Mobility for US\$12.5 Billion, PC WORLD, http://www.pcworld.com/article/238043/google_buys_motorola_mobility_for_us_12_5_billion. html (last visited Nov. 14, 2015). Indeed, following that acquisition, Google sold off all of Motorola's businesses except for its patent portfolio. Jeff Roberts, Google Paid \$4B for Patents: Why the Motorola Deal Worked Out Just Fine, GIGAOM (Jan. 30, 2014, 5:15 AM), https://gigaom.com/2014/01/30/google-paid-4b-for-patents-why-the-motorola-deal-worked-outjust-fine/.

16. See Dana Cimilluca \& Sam Schechner, Alcatel-Lucent Secures $\$ 2.1$ Billion Debt Financing, WALL ST. J. (Dec. 14, 2012, 9:47 AM), http://www.wsj.com/articles/SB10001424127887323981504578177982789220970.

17. KeVIn G. RivetTe \& David KLINE, REMBRANDTS IN the AtTiC: Unlocking the HIDDEN VALUE OF PATENTS 28 (2000). 
portfolios. ${ }^{18}$ Others have sold their patents outright either to other operating companies or a whole new class of enterprises ${ }^{19}$ - patent assertion entities; more pejoratively, patent trolls-that "purchase patents, and then sell or license them as assets whose values are based on the amount of licensing fees" or litigation recoveries they can obtain. ${ }^{20}$ Finally, intermediaries have arisen to facilitate these transactions. Ocean Tomo, for example, links buyers and sellers of patents through an auction process, ${ }^{21}$ while a company called IPXI purported to create "the world's first financial exchange that facilitates non-exclusive licensing and trading of intellectual property (IP) rights with market-based pricing and standardized terms." ${ }^{22}$ In short, patents no longer are used solely to exclude competitors; instead, they frequently are bought and sold by persons or entities other than the inventors whose work falls within the patent claims.

More important, the growth of this market is leading to a significant shift in the discourse, in which patents are treated not as classic incentives for innovation, but as financial assets. After all, they meet the typical definition of financial assets-they are transferable "claim[s] to future cash flow[s]." The right to exclude conferred by a patent can generate cash for its holder when the underlying subject matter is licensed to others or the right to exclude is enforced through litigation. To be sure, the cash flow associated with any given patent is highly uncertain. ${ }^{24}$ It depends on the vagaries of licensing negotiations or litigation. But valuation amidst significant

18. See Mark A. Lemley \& A. Douglas Melamed, Missing the Forest for the Trolls, 113 CoLUM. L. REV. 2117, 2137-38 nn.89-94 (2013) (collecting examples).

19. See Michael Risch, Patent Troll Myths, 42 Seton Hall L. REV. 457, 461 (2012) (concluding that most NPE patents came from operating companies selling parts of their portfolios).

20. FTC REPORT, supra note 12 , at 60 .

21. See Press Release, Ocean Tomo, Ocean Tomo to Re-Enter Live Intellectual Property (IP) Auction Market (Oct. 6, 2014, 12:00 AM), http://www.oceantomo.com/2014/10/06/oceantomo-re-enter-live-intellectual-property-ip-auction-market/.

22. See Press Release, Intellectual Property Exchange International, Inc., Intellectual Property Exchange International Attracts Leading Global Corporations, Universities, National Laboratories as New Members (May 25, 2012), https://www.ipxi.com/news-events/news/pressreleases/69-ipxi-attracts-leading-members.html. IPXI since proved unsuccessful, closing in March 2015.

23. FABOZZI ET AL., supra note 8, at 2.

24. See Mark A. Lemley \& Carl Shapiro, Probabilistic Patents, 19 J. ECON. PERSP. 75, 76 (2005) [hereinafter Lemley \& Shapiro, Probabilistic Patents] ("There are two fundamental dimensions of uncertainty: 1) uncertainty about the commercial significance of the invention being patented, and 2) uncertainty about the validity and scope of the legal right being granted."). 
uncertainty is what much of finance tries to accomplish, ${ }^{25}$ and a number of methods have been developed to assign a monetary value to a patent. ${ }^{26}$

Much of the academic commentary on these developments has focused on how to improve the operation of this nascent market. Nathan Myhrvold and Mark Lemley, for example, argue that price transparency is the sine qua non of a sustainable market and that in order to "make a patent market," patent assignment and license terms should be subject to mandatory disclosure. ${ }^{27}$ Michael Risch argues in a similar vein that the securities laws ought to apply to patent portfolios..$^{28}$

In the public discourse about "patent trolls," many entities accused of trolling behavior defend their activities on the ground that they are trying to establish a patent market. Nathan Myhrvold, the CEO of Intellectual Ventures, the largest patent aggregation firm, describes his firm as "trying . . . to create a capital market for inventions." 29 "To organize such a market," he says, "you need the liquidity that only investors can provide." 30 Several academic authors have made similar claims, observing that patent assertion entities really are intermediaries in the patent market. ${ }^{31}$ As such, they "make the patent market more efficient by realigning market participant incentives, making patents more liquid, and clearing the patent market." 32 Microsoft summarized the case in its recent comments to the FTC:

25. See Stephen A. Ross et AL., Corporate Finance 49 (2d ed. 1990).

26. See infra notes 100-108 and accompanying text.

27. Lemley \& Myhrvold, supra note 6 , at $258-59$. This position is consistent with broader calls to improve the notice function of the patent system. See, e.g., JAMES BESSEN \& MICHAEL J.

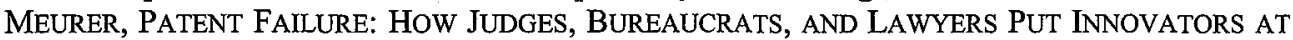
RISK 235-53 (2008).

28. Michael Risch, Patent Portfolios as Securities, 63 DukE L.J. 89, 93 (2013) [hereinafter Risch, Patent Portfolios] ("[T]his Article proposes that patent portfolios, but perhaps not individual patents, should be treated like securities to help patent markets behave more like public securities markets.").

29. Myhrvold, supra note 4.

30. Id.

31. See Hagiu \& Yoffie, supra note 11, at 46; James F. McDonough III, Comment, The Myth of the Patent Troll: An Alternative View of the Function of Patent Dealers in an Idea Economy, 56 EMORY L.J. 189, 190 (2008).

32. McDonough, supra note 31 ; see also B. Zorina Khan, Trolls and Other Patent Inventions: Economic History and the Patent Controversy in the Twenty-First Century, 21 GEO. MASON L. REV. 825, 835 (2014) ("[I]n many [historical examples], 'speculators' invested in patents with the sole intention of profiting from the margins of price differentials, without participating in either inventive activity or manufacturing, much as a financial investor might trade in a share in a company in secondary and tertiary markets. In so doing, they added to the liquidity and depth of the market and enabled others to minimize their exposure to risk."); Kristen Osenga, Formerly Manufacturing Entities: Piercing the "Patent Troll" Rhetoric, 47 
PAEs (and patent aggregators more generally) have made significant strides in adding liquidity, market clearing, and risk transfer mechanisms to the patent market. Their market participation by serving as "ready and willing" buyers of patents helps manage the supply of patents and provides liquidity to the patent market. Patent intermediaries' expertise in evaluating patent assets also leads to better information, more rational pricing, and lower transaction costs in the secondary market. ${ }^{33}$

These observations and arguments are likely correct so far as they go. It is self-evident that more willing buyers create greater liquidity for patents, and that improving the notice function of the patent system will reduce the information costs associated with patent transactions. In short, there are many steps that policymakers and private sector actors can take to create more robust, liquid patent markets. But should they? There appears to be an underlying normative premise to these arguments: that those robust, liquid patent markets would be socially beneficial. That premise has, for the most part, ${ }^{34}$ gone unexamined. ${ }^{35}$

To challenge that premise, I draw upon the financial economics literature to develop the analogy between patent markets and financial markets. This analogy ultimately offers a mixed bag. There are some circumstances in which patent markets are likely to be socially desirable, but others in which they may be prone to well understood market failures. I begin by articulating the relevant normative standard, because transactional efficiency in itself is neither the goal of the patent system nor of financial markets. Indeed, efficient markets that match buyers and sellers of a particular asset are not usually thought to be ends in themselves; instead they are instrumentally useful when they serve other social goals, such as allocating useful goods and services or mitigating risk. Because the primary normative goal of the patent system is generally thought to be innovation promotion, the efficacy of patent markets ought to be judged not simply by

CONN. L. REV. 435, 452 (2014) ("[P]atent licensing companies also engage in the all-important function of market-making by adding liquidity to patents and reducing information asymmetries between buyers and sellers.").

33. Jason Albert, Comments of Microsoft Corporation on the Impact of Patent Assertion Entity Activities on Innovation and Competition, MICrosofT CORP. 5-6 (2012), http://www.justice.gov/atr/public/workshops/pae/comments/paew-0042.pdf.

34. A prominent exception is Robert P. Merges, The Trouble With Trolls: Innovation, Rent-Seeking, and Patent Law Reform, 24 BERKELEY TECH. L.J. 1583 (2009). Merges argues that there is no justification for a market in socially wasteful patent transactions. Id. at 1588. See infra notes 164-65 and accompanying text.

35. E.g., Risch, Patent Portfolios, supra note 28, at 95 (expressly reserving the question). 
the extent to which they match buyers and sellers, but by the extent to which they promote or retard innovation.

With this analogy in mind, there are two potential functions that robust patent markets can play. First, they can allocate technology. When patents correlate with technologically useful knowledge, markets can enable real technology transfer between inventors who need capital or skills and developers or commercializing agents who possess those things. That in turn has innumerable benefits because it allows for faster, better commercialization of new technologies. But where the fit between patents and technologies is imperfect, there is ample room for strategic behavior. A liquid market may exacerbate rather than ameliorate those behaviors because the pricing mechanism in a liquid market may more easily and quickly incorporate information about litigation value than commercialization value. In those circumstances, patents become inefficient assets. Their value in a market fails to reflect the value of the underlying technology. Market allocation of such assets may then be suboptimal from the perspective of social welfare.

Patent markets may produce similarly indeterminate results with respect to their second major function: allocating the various risks of innovation. On one hand, giving inventors an option to sell their patents rather than commercializing or enforcing them makes it far easier to earn a return, and thereby to mitigate the market risk of invention. Market pricing can also allow parties to mitigate infringement risk in a less costly manner than through litigation. But patent markets may give rise to a particular moral hazard problem in which inventors seeking only monetary returns no longer have an adequate incentive to monitor patent quality. The result is a dynamic not unlike that which affected markets for subprime mortgages and their associated securities in the late aughts. A market for an inefficient asset may simply produce more of that asset.

If we take seriously, then, both the analogy between patents and financial assets and the normative goal of promoting innovation, the social value of patent markets becomes ambiguous. The difficult policy problem is to determine when one or another of these effects will dominate. That depends on a number of factors that are likely to be context-specific. How good a unit of technological exchange is a patent? How close is the fit in any given industry between patents and technologies? How many and what kinds of sellers and buyers are present in any given "sub-market" for a particular technology? And so forth. Understanding the dynamics of any particular patent market requires empirical research. This Essay therefore marks the beginning rather than the end of the conversation about patent markets. It offers a framework within which to carry out the difficult task of 
assembling empirical data. In the meantime, however, the theoretical discussion at least supports two related conclusions. First, patent markets are unlikely to be unqualified social goods. And, second, we therefore should not abandon efforts to improve patent quality in the mistaken belief that a well-functioning market will cure what ails our current system.

\section{NoRMATIVE BASELINES}

A necessary first step in assessing the desirability of patent markets is to identify just what such markets are supposed to accomplish. The proponents of strong patent markets appear to view efficiency in patent transactions as the paramount normative goal. ${ }^{36}$ To be sure, there are benefits to clearing the market - to allocating all given assets to those who are willing to pay market prices for those assets. But transactional efficiency is not the sole goal either of the patent system or, for that matter, of modern capital markets.

Begin with the patent system. The constitutional purpose of intellectual property is "[t]o promote the [p]rogress of [s]cience and useful [a]rts." Though debate over the proper aims and scope of the patent system is legion, most agree that, at a minimum, it exists to promote innovation. ${ }^{38}$ Patents can serve this purpose in several ways. ${ }^{39}$ The classic justification for patents is that they provide incentives to invest in innovation. ${ }^{40} \mathrm{It}$ is usually thought that an unregulated market will under-supply innovation because it is risky and expensive, but its product-information - is cheap and easy to copy. ${ }^{41}$ By conferring upon inventors the legal right to exclude others from

36. See, e.g., McDonough, supra note 31, at 216-18.

37. U.S. CONST. art. I, $\S 8, \mathrm{cl} .8$.

38. See, e.g., SUZANNE SCOTCHMER, INNOVATION AND INCENTIVES 38 (2004) ("Intellectual property protection gives innovators an incentive to invest in new knowledge."). Innovation is the broader process of bringing new products and processes into the world, of which invention is only a part. See, e.g., JOSEPH A. SCHUMPETER, CAPITALISM, SOCIALISM AND DEMOCRACY 84 (2d ed. 1947).

39. For the purpose of this analysis, I put to the side non-utilitarian theories of patent law. See generally ROBERT P. MERgES, JUSTIFYING INTELleCtUAL PROPERTY (2011); William Fisher, Theories of Intellectual Property, in NEW ESSAYS IN THE LEGAL AND POLITICAL THEORY OF PROPERTY 168, 170-71 (Stephen R. Munzer ed., 2001). The development of robust, liquid patent markets likely has little bearing on the policy conclusions that would follow from nonutilitarian theories.

40. See Fisher, supra note 39, at 178.

41. See Kenneth J. Arrow, Economic Welfare and the Allocation of Resources for Invention, in THE RATE AND DIRECTION OF INVENTIVE ACTIVITY: ECONOMIC AND SOCIAL FACTORS 609, 616-19 (1962); Richard R. Nelson, The Simple Economics of Basic Scientific Research, 67 J. POL. ECON. 297, 302-04 (1959). 
their inventions, patents render appropriable otherwise non-rivalrous and non-excludable information. This is turn allows those inventors potentially to recoup their investment in R\&D, which would otherwise be free for others to take. ${ }^{42}$ The grant of exclusive rights in an invention comes with social $\operatorname{costs}^{43}$ : the static deadweight loss that arises from pricing information above its marginal cost (of zero), ${ }^{44}$ and the dynamic social welfare losses that arise because information is an input into the downstream production of further information. ${ }^{45}$ Most debates about the desirability of intellectual property, or of changes to existing intellectual property law, attempt to determine the magnitude of the tradeoff between these benefits and costs.

A variety of other potential justifications for patents have been proposed within the basic utilitarian framework. ${ }^{46}$ Most relevant for the analysis of patent markets, and described in further detail below, ${ }^{47}$ is the idea that patents play a role not only in invention but also in commercialization, the process of bringing an inventive product from conception through development to marketing. This justification is usually thought to have its origins in the work of Edmund Kitch, who analogized patents to mining claims, and argued that broad patents give their owners incentive to maximize their value by controlling their development and commercialization. ${ }^{48}$ Contemporary accounts suggest two distinct roles

42. For standard accounts of the incentive theory of intellectual property, see, e.g., SCOTCHMER, supra note 38, at 34-38; Peter S. Menell \& Suzanne Scotchmer, Intellectual Property, in 2 HANDBOOK OF LAW AND ECONOMICS 1473, 1477-78 (A. Mitchell Polinsky \& Steven Shavell eds., 2007).

43. These costs are well summarized in Mark A. Lemley, Property, Intellectual Property, and Free Riding, 83 TEX. L. REV. 1031, 1058-59 (2005) ("First, intellectual property rights distort markets away from the competitive norm, and therefore create static inefficiencies in the form of deadweight losses. Second, intellectual property rights interfere with the ability of other creators to work, and therefore create dynamic inefficiencies. Third, the prospect of intellectual property rights encourages rent-seeking behavior that is socially wasteful. Fourth, enforcement of intellectual property rights imposes administrative costs. Finally, overinvestment in research and development is itself distortionary.").

44. See SCOTCHMER, supra note 38, at 36-37; Arrow, supra note 41, at 617.

45. See Arrow, supra note 41, at 618; Suzanne Scotchmer, Standing on the Shoulders of Giants: Cumulative Research and the Patent Law, 5 J. ECON. PERSP. 29, 30 (1991).

46. Two such justifications merit mention but not significant detail. One is disclosure. Patents can facilitate the codification and distribution of useful information about the inventions that are the subject of patent claims. See Jeanne C. Fromer, Patent Disclosure, 94 IowA L. REV. $539,541-42$ (2009). The other is signaling, whereby patents serve as an indicator of value to others. See Clarisa Long, Patent Signals, 69 U. CHI. L. REV. 625, 627-28 (2002). These justifications are tangential to the impact of markets described here.

47. See infra Section II.A.1.

48. See Edmund W. Kitch, The Nature and Function of the Patent System, 20 J.L. \& ECON. 265, 275-80 (1977). 
patents might play in facilitating innovation even after they issue. ${ }^{49}$ They can provide incentives for commercialization ${ }^{50}$ or they can facilitate linkages between inventors and sources of development expertise or financing. ${ }^{51}$ Debate regarding the former mostly mirrors the debate over using patents to incentivize invention in the first instance. ${ }^{52}$ There remain serious questions about whether a commercialization market failure exists and, if so, whether patents are the socially optimal solution to that market failure..$^{53}$ As to the latter, I have argued in previous work that patents are not necessary to facilitate the exchange of valuable information. ${ }^{54}$ But as described in Section II.A, there may be instances in which they are useful to accomplish that goal, as loci for bargaining and for the exchange of tacit knowledge.

The point here is not to resolve these questions. It is instead to highlight the common normative backdrop: patents are not naturally occurring phenomena with a value-neutral allocation scheme. ${ }^{55}$ They are "government interventions in the marketplace designed to achieve social policy ends." They exist only to the extent that we continue to believe they produce more social welfare gains in the form of increased innovation than social welfare losses in denied access to those innovations. ${ }^{57}$ Most debates about the patent system today concern whether particular changes to the substantive or

49. For criticism of the theory that patents are justified by more than their ability to incentivize invention in the first instance, see Mark A. Lemley, Ex Ante Versus Ex Post Justifications for Intellectual Property, 71 U. CHI. L. REV. 129, 131-32 (2004) [hereinafter Lemley, Ex Ante].

50. See, e.g., Michael Abramowicz, The Danger of Underdeveloped Patent Prospects, 92 CoRnell L. ReV. 1065, 1068-70 (2007); Ted Sichelman, Commercializing Patents, 62 STAN. L. REV. 341, 373-76 (2010). The incentive-to-commercialize theory of patents is not economically distinct from the incentive-to-invent theory. See Michael J. Burstein, Reply-Commercialization Without Exchange, 92 TEX. L. REV. SEe ALso 45, 46-49 (2014) [hereinafter Burstein, Reply].

51. See, e.g., Jonathan M. Barnett, Intellectual Property as a Law of Organization, $84 \mathrm{~S}$. CAL. L. REV. 785, 792 (2011); Robert P. Merges, A Transactional View of Property Rights, 20 BERKELEY TECH. L.J. 1477, 1519 (2005).

52. See Burstein, Reply, supra note 50, at 49-51.

53. Compare Abramowicz, supra note 50, at 1074-75, and Sichelman, supra note 50, at 348-49, with Lemley, Ex Ante, supra note 49, at 136-41, and Mark A. Lemley, The Myth of the Sole Inventor, 110 MiCH. L. REV. 709, $738-49$ (2012).

54. See Michael J. Burstein, Exchanging Information Without Intellectual Property, 91 TEX. L. REV. 227, 282 (2012) [hereinafter Burstein, Exchanging Information].

55. Cf. Adam Mossoff, Who Cares What Thomas Jefferson Thought About Patents? Reevaluating the Patent "Privilege" in Historical Context, 92 CORNELL L. REV. 953, 1011-12 (2007) (situating patents in context of natural rights theory).

56. Mark A. Lemley, Taking the Regulatory Nature of IP Seriously, 92 TEX. L. REV. 107, 110 (2014).

57. Id. 
procedural rules governing patents will be better or worse for innovation. There is no reason why the system for allocating patent rights should be exempt from those debates. The question whether we should have liquid markets for patents, in other words, ought to be judged by the same standard as the question whether we should have patents at all.

What about financial markets? Here too, liquidity and efficiency are not ends in themselves. Instead, the financial economics literature posits two goals for financial markets: allocating assets to their highest value uses, and allocating risk to the least-cost risk bearers. ${ }^{58}$ Think, for instance, of futures contracts. These are contracts in which one party promises to deliver a certain amount of a commodity-say wheat, or copper-at a particular price on a particular date. ${ }^{59}$ When a contract is bought and sold, the market allocates to the buying party both a claim to the underlying commodity and the risk that the price of that commodity will change. ${ }^{60}$ The asset and the risk are allocated to the party that is willing to pay a particular price, reflected in the market price of the contract, for those things. ${ }^{61}$

Liquid markets aid this allocation in several ways. First, they provide price information by aggregating the preferences of buyers and sellers as expressed in market transactions. Second, they ensure the availability of opportunities for welfare enhancing transactions. The more willing buyers and sellers there are, the more likely it is that the socially optimal allocation will be achieved. Third, they lower transaction costs. They make it easier for buyers and sellers to find one another, thereby reducing "search costs." And they lower the cost of generating information necessary for those buyers and sellers to reach a negotiated bargain, usually by putting in place mechanisms that make it easier for market participants to assess the value and characteristics of the goods to be traded.62 The important point, however, is that these functions of markets are instrumental. Liquidity makes it easier to transfer assets from one party to another. ${ }^{63}$ But the social

58. See FABOZZI ET AL., supra note 8, at 4, 283. Indeed, capital markets are deemed "complete" as a matter of theory, when one can invest capital in and insure against the risk of every possible state of the world. See Kenneth J. Arrow, The Role of Securities in the Optimal Allocation of Risk-Bearing, 31 REV. ECON. STUD. 91, 91 (1964); see also Ronald J. Gilson \& Charles K. Whitehead, Deconstructing Equity: Public Ownership, Agency Costs, and Complete Capital Markets, 108 CoLUM. L. REV. 231, 232-33, 232 n.7 (2008).

59. See FABOZZI ET AL., supra note 8 , at 535 .

60. Id. at $356-37$.

61. Id.

62. See id. at 5-6.

63. See id. at 5 . 
utility of markets is derivative of the social utility of the goods that trade on them.

The view that market efficiency is instrumental rather than a good in itself is reflected most clearly in the ongoing debates about financial innovation. "Financial innovation" refers to the development of new financial products such as derivatives, credit instruments, and various forms of tradable securities used to allocate risk, and their incorporation into the existing institutional structure of markets and intermediaries. ${ }^{64}$ Were efficiency in the purchase and sale of financial products the sole goal of financial markets, one would think that markets in complex financial products would be generally unobjectionable. But a significant debate has emerged, particularly following the financial crisis of 2008-09 about the desirability of continued financial innovation. ${ }^{65}$ In answering the question whether one or another particular financial instrument is socially valuable, participants in this debate usually draw a distinction between financial markets and the "real economy." that are the subject of trades; the former comprises those instruments that are used either to fund the real economy or to guard against its risks. ${ }^{67}$ Financial products, even if they are traded efficiently in a liquid market "are socially beneficial when they help people insure risks"68 or when they allocate capital or commodities. But when they fail to carry out those functions, trading in them amounts to "gambling [which] can instead be socially detrimental." 69 It stands to reason that liquid markets for socially harmful products are themselves socially harmful.

Putting together the rationales for patents and for financial markets yields a normative baseline for the analysis that follows. Liquid markets for patents should be evaluated based on the extent to which they promote innovation. After all, if patents are justified only to the extent that they are socially useful, it follows a fortiori that, markets in patents should only exist if they are socially useful.

A well-functioning patent market would carry out two distinct tasks. Like a market for futures contracts, as described above, or any other

64. See id. at 15-16; Zachary J. Gubler, The Financial Innovation Process: Theory and Application, 36 DEL. J. CORP. L. 55, 62 (2011).

65. See, e.g., RoBert J. SHILlER, FINANCE AND THE GOOD SOCIETY 12-14 (2012).

66. See, e.g., Eric A. Posner \& E. Glen Weyl, An FDA for Financial Innovation: Applying the Insurable Interest Doctrine to Twenty-First Century Financial Markets, 107 Nw. U.L. REV. 1307, 1313 (2013); see also FABOZZI ET AL., supra note 8, at 1-2.

67. See Posner \& Weyl, supra note 66, at 1313-16.

68. Id. at 1308 .

69. Id. 
financial asset, it would allocate both the underlying asset and the risks associated with that asset. A patent is a time-limited, exclusive right to make, use, or sell a particular claimed invention. It is analogous to the futures contract. The underlying asset is not a commodity like wheat, but the invention that is the subject of the patent claims. ${ }^{70}$ Assigning a patent to a particular person, either the inventor, as current law does as an initial matter, ${ }^{71}$ or a subsequent market buyer, ${ }^{72}$ allocates to that person both a claim to the underlying invention and a set of risks associated with that invention. A market for patents would allocate innovation's underlying asset - technology - and the dual risks of innovation and infringement. The next section will explore whether and how markets for patents might achieve socially useful allocations of those things.

\section{EVAluating Patent MARkets}

This Section envisions a hypothetical patent market and evaluates how well such a market might meet the normative goals described above. There are a number of different ways in which one might imagine patents being traded in a market. Patents could trade like stocks. To do so, they would have to be made fungible. That is, one share of common stock is no different from any other share of common stock; they are commodities. It may be possible to structure, say, a holding company whose only asset was a patent or a group of related patents, ${ }^{73}$ and sell shares in that holding company. More likely, however, is that patents will remain bespoke rather than commoditized. That is, each patent is likely to remain unique and distinct from each other patent. Markets in such goods nevertheless can develop and function in predictable ways. The real estate market, for example, is often a liquid market in differentiated goods. So too are markets for certain financial products like derivatives.

To simplify the hypothetical patent market, I focus on three characteristics that would obtain regardless of its particular structure. The first is liquidity. The market would have enough willing buyers and sellers of patents that most contemplated trades would be executed. The second is price taking. No single player in the market would be so large as to unduly

70. Note that although the underlying asset is the invention, it can be difficult in practice to separate the invention from the patent. See Martin \& Partnoy, supra note 3, at 310-11.

71. See 35 U.S.C. $\S \S 151-152$ (2012) (presumption that patent is issued to inventor).

72. See id. $\S 261$ (assignment of ownership).

73. Cf. Risch, Patent Portfolios, supra note 28, at 104-05 (describing holding companies for patent portfolios). 
influence the prices that the market generates. In other words, transactions would take place at the market-clearing price. Third, there would be enough institutional infrastructure to support transparency as to prices and characteristics of transacted patents.

To be sure, there are many complications. Two merit a few further words. First, in the contemporary, non-hypothetical market, many firms build packages of related patents that may be traded as a group. ${ }^{74}$ The complementarity of patents in a portfolio often makes the value of the whole greater than the sum of its parts. ${ }^{75}$ This phenomenon makes patent valuation particularly complicated ${ }^{76}$ and casts some doubt on whether individual patents and portfolios ought to be treated similarly. ${ }^{77}$ Nevertheless, although valuation may be different with respect to individual or aggregated patents, the behavior of those two asset classes in a liquid market is likely to be similar. Second, the institutional details - what kinds of patents are being traded, who are buyers and sellers and what are their characteristics, who are the market makers and what are the rules that they set, how are trades recorded and publicized, and so on-do matter. ${ }^{78}$ That said, the analysis that follows is, for the most part, neutral with respect to the institutional details.

\section{A. Allocating Technology}

One function a liquid patent market could play is to facilitate the exchange of useful technologies, helping to ensure that they wind up in the hands of their highest value users. In other words, the market for patents is like the market for secondhand goods. Patents usually are issued first to inventors. But just like the secondary market for tangible goods allocates a resource-vintage jeans, say-from an original to the subsequent user that values it the highest, so too can a secondary patent market use price signals to allocate technology to its highest and best use. More specifically, patent markets can link inventors with sources of development skill and financial

74. See Gideon Parchomovsky \& R. Polk Wagner, Patent Portfolios, 154 U. PA. L. REV. 1, 27 (2005).

75. See id. ("[T]he real value of patents lies not in their individual significance, but instead in their aggregation into a patent portfolio ....").

76. See Hagiu \& Yoffie, supra note 11 , at 46-47.

77. See Risch, Patent Portfolios, supra note 28, at 102-03 (arguing that application of securities laws to individual patents would be more costly than beneficial).

78. But cf. FABOZZI ET AL., supra note 8, at 283-88 (describing structural variations among different kinds of secondary capital markets). 
capital to do what the inventors themselves cannot: bring a product from the laboratory to the shelf.

There is, however, a difference between markets for technology and markets for patents. And arguments for the former may not always justify the latter. It is blackletter patent law that patents are solely negative rightsthey are rights to exclude. ${ }^{79}$ The simple analogy between markets for patents and for tangible goods is therefore not quite right. It is the technology that is analogous to the vintage jeans, not necessarily the patent. The underlying technology is a resource that can be put to productive use; the patent is a legally created right to prevent others from engaging in that use. When this right to exclude is similar in scope to the underlying technology, then it can aid in the technological exchange that I describe above. But when that fit is imperfect, the risk of strategic behavior may become significant. And in that case, the pricing function of liquid patent markets may not produce optimal results.

\section{Patents and the Market for Technology}

An account of the positive impact of liquid markets for patents in facilitating technological exchange begins with two premises: tech transfer is important; and it is difficult to accomplish. A wave of recent scholarship has emphasized the importance of commercialization ${ }^{80}$ Invention is merely the beginning of a broader process of innovation, in which new ideas not only are generated, but also are developed and brought to market. ${ }^{81}$ Those latter functions, which are what catalyze real social benefits, often require skills that the initial inventor of a technology does not have. To bring those skills to bear and turn an idea into a useful product, an inventor usually must seek out others - development partners, product designers, manufacturing engineers, and so on. And commercialization is costly; often requiring more financial resources than inventors themselves may possess.

79. See 35 U.S.C. $\S 271$ (2010). ("[W]hoever without authority makes, uses, offers to sell, or sells any patented invention, within the United States or imports into the United States any patented invention during the term of the patent therefor, infringes the patent.").

80. Edmund Kitch's work is often cited as the foundation of this line of inquiry. See Kitch, supra note 48, at 267-71 (analogizing patents to mining prospects and arguing that exclusive rights promote subsequent development). For more recent contributions, see, for example, Abramowicz, supra note 50, at 1068-70; Camilla Alexandra Hrdy, Commercialization Awards, 2015 WIS. L. REV. 13, 29 (2015); F. Scott Kieff, Property Rights and Property Rules for Commercializing Inventions, 85 MINN. L. REV. 697, 717 (2001); Sichelman, supra note 50, at 373-76.

81. See SCHUMPETER, supra note 38 , at 84 ; Sichelman, supra note 50, at 348-54. 
But contracting over technology is notoriously difficult. Kenneth Arrow famously articulated a "fundamental paradox" that arises when parties try to contract for the sale of information. ${ }^{82}$ The buyer of information must be able to place a value on the information and determine how much she is willing to pay. But once the seller discloses the information, the buyer is in possession of the subject of the trade and no longer has any reason to pay for it. ${ }^{83}$ Intellectual property is one way to solve the paradox. If the information that parties want to trade is protected by a patent, then it can be disclosed freely without fear of misappropriation. ${ }^{84}$ "With suitable legal measures," Arrow writes, "information may become an appropriable commodity." 85

In previous work, I have criticized the reflexive turn to intellectual property to facilitate the exchange of valuable information. ${ }^{86}$ Intellectual property is not in fact necessary to accomplish technological exchange, ${ }^{87}$ and often it is not sufficient either. ${ }^{88}$ Solving the disclosure paradox therefore does not offer an independent justification for intellectual property and changes to the contours of existing IP doctrines for the sake of facilitating transactions need to take account of the relative social welfare costs and benefits of other means by which parties might successfully engage in technological exchange. ${ }^{89}$

All that said, there are circumstances in which patents can reduce the transaction costs of technological exchange; and some circumstances in which they may do so optimally when compared with the existing alternatives..$^{90}$ Most straightforwardly, patents can solve the disclosure paradox and create for the parties an identifiable res over which to bargain. ${ }^{91}$ As Kitch explains, patents "create[] a defined set of legal rights known to both parties at the outset of negotiations." $"$ The parties can then

82. Arrow, supra note 41 , at 615 .

83. Burstein, Exchanging Information, supra note 54, at 229; see Arrow, supra note 41, at 615.

84. See Burstein, Exchanging Information, supra note 54, at 229, 229 n.5.

85. Arrow, supra note 41, at 615.

86. See Burstein, Exchanging Information, supra note 54, at 282.

87. See id. at 274-76.

88. See infra notes 103-08.

89. See Burstein, Exchanging Information, supra note 54, at 262-74 (describing use of selective revelation, contract- and norms-based strategies).

90. See id. at 278-79.

91. See, e.g., Dan L. Burk \& Brett H. McDonnell, The Goldilocks Hypothesis: Balancing Intellectual Property Rights at the Boundary of the Firm, 2007 U. ILL. L. REV. 575, 583-90 (2006).

92. Kitch, supra note 48 , at 278. 
bargain for the allocation of those rights. Assuming that the scope of the rights correlates with the scope of the technology, a transaction in the former very closely approximates a transaction in the latter. There is some historical evidence that patents played a significant role in establishing markets for technologies. ${ }^{93}$ Merges argues more specifically that patents provide an especially effective form of "precontractual liability" that allows parties to make disclosures of information not protected by a patent while still holding negotiating partners liable for misappropriation of the related information that fall within the boundaries of the patent claim. ${ }^{94}$ Kieff focuses on the notice function of the patent, arguing that as a public document, it serves as a "beacon" to draw together interested collaborators. ${ }^{95}$

Patents can lower transaction costs even in the more common situation in which they themselves are insufficient to complete the technology transfer. Often the disclosure of the patent is not enough actually to practice the technology. Much technology transfer, for example, requires not only the transfer of patented knowledge, but also the transfer of tacit knowledge that is critical to practicing the patent. Notwithstanding that patents are supposed to be drafted in such a way as to "enable any person skilled in the art ... to make and use the same," frequently insufficient to allow full exploitation of the underlying technology. ${ }^{97}$ In that circumstance, different mechanisms such as personal connections and organizational integration must facilitate the transfer of the non-codified knowledge. ${ }^{98}$ That knowledge is especially susceptible to the moral hazard problem reflected in the disclosure paradox..$^{99}$ But patents can potentially lower the transaction costs associated with tacit knowledge

93. See, e.g., B. Zorina KHAN, The Democratization of InNOvation: Patents And COPYRIGHTS IN AMERICAN ECONOMIC DEVELOPMENT, 1790-1920, 314 (2005); Naomi R. Lamoreaux, Kenneth L. Sokoloff \& Dhanoos Sutthiphisal, Patent Alchemy: The Market for Technology in US History, 87 BUS. HIST. REV. 3, 5 (2013).

94. See Merges, supra note 51, at 1488.

95. See, e.g., F. Scott Kieff, Coordination, Property, and Intellectual Property: An Unconventional Approach to Anticompetitive Effects and Downstream Access, 56 EMORY L.J. 327, 333-34; see also Daniel F. Spulber, How Patents Provide the Foundation of the Market for Inventions, 11 J. COMPETITION L. \& ECON. 2 (describing several ways patents facilitate market for including exclusion, transferability, disclosure, certification, standardization, and divisibility), http://ssrn.com/abstract $=2487564$.

96. 35 U.S.C. $\$ 112$ (a) (2012).

97. See Peter Lee, Transcending the Tacit Dimension: Patents, Relationships, and Organizational Integration in Technology Transfer, 100 CALIF. L. REV. 1503, 1519-20 (2012).

98. See id. at 1521-40.

99. See Ashish ARora et AL., Markets for Technology: The Economics of INNOVATION AND CORPORATE STRATEGY 117-18 (2001). 
transfers by "exploiting the complementarity between know-how and any other technology input that the licensor can use as a "hostage," such as a patent. ${ }^{100}$ In that circumstance, the transferring party can threaten to withhold the patented component of the technology, as it is legally entitled to do, should the transferee party misappropriate the tacit knowledge. ${ }^{101}$

To sum, the strong case that patents are necessary for technology transfer is likely wrong, but there are circumstances in which patents will lower the costs of such transfer. Now add a liquid market. Patent markets are likely to reduce transactions costs further still because they act on different dimensions of the costs of trade. In a liquid market, buyers and sellers are transparent to one another. This lowers search costs, including both "explicit costs, such as the money spent to advertise one's intention to sell or purchase" the patents, and "implicit costs, such as the value of time spent in locating a counterparty." 102 The presence of a large number of potentially interested parties makes it much more likely that compatible inventors and developers will find one another. A liquid market could also lower the information costs associated with the transaction by standardizing information across market participants. ${ }^{103}$ Finally, and perhaps most importantly, liquidity would provide some measure of price information that would ease the cost of negotiating from relatively uninformed positions.

\section{Patent Liquidity and Pricing}

The dynamic described above is most likely to obtain when the transfer of a patent enables the transfer of new and useful technology. ${ }^{104}$ There are two circumstances in which that might fail to occur. The first is when a patent claims subject matter that is obvious or not novel. Such a patent

100. Id. at 116 .

101. See id.; see also Joshua S. Gans \& Scott Stern, The Product Market and the Market for Ideas: Commercialization Strategies for Technology Entrepreneurs, 32 RES. POL'Y 333, 338 (2002).

102. See FABOZZI ET AL., supra note 8, at 6.

103. Id.

104. A note on nomenclature: I use "technology" here as "an imprecise term for useful knowledge rooted in engineering and scientific discliplines, but also drawing from practice experience with production." ARORA ET AL., supra note 99, at 3 . It is well understood that there is a difference between patents and marketed products. The distinction I draw here is somewhat different. I posit that there are meaningful units of technological exchange-complete technologies to be used in one or more product markets that can be the subject of transfer between their inventors and third party sources of development expertise and financing that need not necessarily correlate with products. 
should not have issued in the first place, and therefore does not transfer technology that otherwise would have gone undeveloped. ${ }^{105}$ An efficient market for trading invalid rights merely exacerbates the social welfare losses associated with those invalid rights. ${ }^{106}$ I consider separately in Section II.B whether markets may offer a second-best solution to the problem of "clearing" invalid patents.

But even valid and infringed patents may diverge from the scope of economically useful technology. Patents can be too broad or too narrow. When this happens, there is significant room for strategic behavior. Take two common examples: software and biotech. Software claims are often functional in nature and broad. ${ }^{107}$ As a result, they tend to cover many different technologies that parties might exchange. In biotech, the opposite problem sometimes obtains. To the extent that biotech inventions are unduly narrow in scope, technological exchange requires aggregation of many different patents. ${ }^{108}$ In either circumstance, patent holders have the ability to extract rents arguably in excess of the value of the underlying technology. ${ }^{109}$ Both broad software patents and narrow biotech patents may be components of larger technologies. Because the threat of injunctive relief or of significant (sometimes treble) damages, patent holders of this sort often have negotiating leverage. ${ }^{110}$ And because of the cost and uncertainty of litigation, patent holders often can extract nuisance value settlements. The mismatch between patent scope and technological scope, in other words, gives rise to many of the behaviors most associated with socially costly patent trolling. ${ }^{111}$

105. See Michael Abramowicz \& John F. Duffy, The Inducement Standard of Patentability, 120 YALE L.J. 1590, 1597-98 (2011) ("Under a rigorously enforced inducement standard, patents would cover only those innovations that otherwise would not be created or disclosedin other words, patents would cover only innovations that, without the patent system, would not have been in the public domain.").

106. See Merges, supra note 34, at 1603 ("The market for patents unrelated to innovation adds nothing to overall social welfare.").

107. See Mark A. Lemley, Software Patents and the Return of Functional Claiming, 2013 WIS. L. REV. 905, 940-41 (2013).

108. See Michael A. Heller \& Rebecca S. Eisenberg, Can Patents Deter Innovation? The Anticommons in Biomedical Research, SCI., May 1998, at 698, 699.

109. See, e.g., Mark A. Lemley \& Carl Shapiro, Patent Holdup and Royalty Stacking, 85 TEX. L. REv. 1991, 1993 (2007) [hereinafter Lemley \& Shapiro, Patent Holdup].

110. See, e.g., eBay, Inc. v. MercExchange, L.L.C., 547 U.S. 388, 396-97 (2006). In the years since $e B a y$, injunctions have become less frequent but they still offer patent plaintiffs significant leverage ex ante. See FTC REPORT, supra note 12, at 215.

111. See Colleen V. Chien, Of Trolls, Davids, Goliaths, and Kings: Narratives and Evidence in the Litigation of High Tech Patents, 87 N.C. L. REV. 1571, 1577-82 (2009); Lemley \& Melamed, supra note 18, at 2146-53. This dynamic has not yet become widespread in 
Patents are notoriously difficult to value. This should be unsurprising in light of the many contingencies described above that might affect the amount and timing of cash flows that a patent can generate. ${ }^{112}$ While the standard economic analysis of financial assets posits that the value of the asset is net present value of future cash flows, ${ }^{113}$ figuring out how to take the measure of those cash flows is difficult. Although professionals utilize a variety of methods, ${ }^{114}$ economists and legal scholars have focused increasing attention on a concept of patents as options. ${ }^{115}$ In this view, a patent confers upon its holder "the right but not the obligation to make further investments." 116 For the cost of procuring a patent (including the $R \& D$ expense of the invention in the first instance), a patent holder can obtain "the right, at various stages, to purchase a stream of expected cash flows associated with excluding others from developing patented subject matter. Patent holders can monetize this right by developing and commercializing the patent and/or by litigating, or threatening to litigate, the patent." 117 The value of the commercialization option will depend on the cost of developing the invention, ${ }^{118}$ the likelihood that the invention will be successful, and the potential revenues that the invention may generate. ${ }^{119}$ The litigation value depends on a different set of variables relating to the likelihood of success and cost of enforcing the patent in court. ${ }^{120}$ When strategic behavior of the sort described above is possible, the value of the expected cash flows from these two means of exercising the patent option are likely to diverge even more significantly than in the ordinary case. That is the cost of litigation may be dwarfed by the possibility of a large number

biotech, but there are numerous reasons to believe that it will be. See Robin Feldman $\&$ W. Nicholson Price II, Patent Trolling: Why Bio \& Pharmaceuticals Are at Risk, 17 STAN. TECH. L. REV. 773, 776-78 (2014).

112. See, e.g., John M. Golden, Principles for Patent Remedies, 88 TEX. L. REV. 505, 52551 (2010) (describing common problems).

113. See FABOZZI ET AL., supra note 8, at 3 ("A basic economic principle is that the price of any financial asset is equal to the present value of its expected cash flows, even if the cash flow is not known with certainty.").

114. See, e.g., Perel, supra note 1, at 161-70.

115. See Martin \& Partnoy, supra note 3, at 303; Cotropia, supra note 3, at 1129-35.

116. Cotropia, supra note 3, at 1132.

117. Martin \& Partnoy, supra note 3, at 303.

118. Commercialization here can refer either to commercialization by the patent holder alone or by her licensee. In either case, the option value of the patent is tied to the ultimate value of the invention in the market. See Cotropia, supra note 3, at 1138.

119. As Martin and Partnoy write, "the expected cash flows associated with the patent are only those incremental cash flows that would result from the producer's being able to exclude others from selling the product." Martin \& Partnoy, supra note 3, at 308.

120. See id. at 321-23. 
of judgments from a diverse set of defendants who are exposed to a broad patent. ${ }^{121}$

The difference between commercialization and enforcement is similar to the distinction that some draw between ex ante transactions, which occur "before the purchaser has obtained the technology through other means," and ex post transactions, which occur "after the firm accused of infringement has invested in creating, developing, or commercializing the technology." 122 My purpose here is not to engage the debate about the social value of ex post transactions, but instead to ask whether a liquid market is likely to allocate patents to parties whose primary aim is commercialization or enforcement.

The answer to that question depends on which value will be reflected in the market price on a liquid exchange. One of the main benefits of a liquid market, as described above, is that it provides pricing data. The value of the good is determined by the price at which willing buyers will engage in the trade-the market-clearing price. In a liquid market, information cost is a significant determinant of the market-clearing price. Because the information costs associated with determining litigation value often may be lower, market prices could more likely reflect litigation than commercialization value. This in turn has significant implications for the allocation of patent rights.

The starting point for figuring out how markets might price financial assets is usually the efficient capital markets hypothesis. ${ }^{123}$ In its most basic form, the hypothesis states "that in a well-functioning securities market, the prices of [securities] will reflect predictions based on all relevant and available information." 124 More precisely, several forms of the theory posit "informational efficiency"-a condition in which investors cannot expect to make abnormal returns trading on information ${ }^{125}$ - with respect to several different types of information. The "weak" form of the hypothesis holds that market prices incorporate the most public of information: previous pricing information. The "semi-strong" and "strong" versions of the

121. See Cotropia, supra note 3 , at $1146-47$.

122. See FTC REPORT, supra note 12, at 7-8 (emphases omitted); see also Robin Feldman \& Mark A. Lemley, Do Patent Licensing Demands Mean Innovation?, 101 Iowa L. REV. 137, 139 (2015) (finding that little NPE licensing activity results in technology transfer).

123. For a succinct overview, see generally ROSS ET AL., supra note 25, at 332-59.

124. William F. Sharpe, Efficient Capital Markets: A Review of Theory and Empirical Work: Discussion, 25 J. FIN. 418, 418 (1970).

125. See Ronald J. Gilson \& Reinier Kraakman, Market Efficiency After the Financial Crisis: It's Still a Matter of Information Costs, 100 VA. L. REV. 313, 321 (2014) [hereinafter Gilson \& Kraakman, After the Financial Crisis]. 
hypothesis extend that characteristic to all publicly and privately available information, respectively. ${ }^{126}$

In a seminal contribution, Gilson and Kraakman described in detail the mechanisms by which information influences market price. ${ }^{127}$ In their account, the incorporation of information into market price depends on the initial distribution of that information. ${ }^{128}$ That initial distribution is itself a function of information costs. ${ }^{129}$ If "capital market efficiency is a function of information costs, then economizing on information costs pushes the capital market in the direction of greater efficiency." 130 That is to say, the market will achieve greater efficiency with less costly information than more; it will incorporate less costly information into prices more rapidly than more costly information.

This analysis suggests that prices in a liquid patent market will more rapidly incorporate information about litigation value than commercialization value when the former is less costly than the latter, and vice versa. It is difficult to predict which will be which, but in at least some cases, litigation data will be easier to obtain. Consider first the sources of information. Litigation documents, including and especially monetary judgments, are public. The information necessary to make a reasonable assessment of a patent's value in commercialization is highly private. The calculation of a value is also likely to be easier (though, to be sure, not necessarily easy) with respect to litigation. Assessing the strength of a patent in court proceeds at least in the context of well-established legal frameworks, even if the applicability of those frameworks to a particular patent is contingent. Assessing commercialization value, on the other hand, requires consideration of an enormous number of idiosyncratic variablespredictions about the likely market, whether the patent is being commercialized by the inventor or by the inventor working in concert with licensees, what the relative cost structure and competitive advantage of each might be, and so forth. All this is another way of saying that it is easier to generate litigation comparables than commercialization comparables. Sophisticated parties already are using big data techniques to assess the characteristics of litigated patents and make reasonable projections about

126. See Eugene Fama, Efficient Capital Markets: A Review of Theory and Empirical Work, 25 J. FIN. 383 (1970); see also RosS ET AL., supra note 25 at 337-41.

127. See Ronald J. Gilson \& Reinier Kraakman, The Mechanisms of Market Efficiency, 70 VA. L. REV. 549 (1984) [hereinafter Gilson \& Kraakman, Market Efficiency].

128. See id. at 567.

129. See id. at 593-97.

130. Id. at 597 . 
how unlitigated patents might fare. ${ }^{131}$ It is very difficult to undertake a similar exercise for the commercialization scenario. "Because of the unique nature of patents, the 'comparables' can always be distinguished."132

Comparables become even more important for pricing in informationally inefficient markets that trade in non-fungible assets. The efficient capital markets hypothesis applies to markets in economic commodities, such as common stock. ${ }^{133}$ Price aggregation works best when the prices of a large number of trades reflect the value of the same underlying asset. When those assets start to become differentiated from each other, the market price tends to reflect an estimate of value based on comparables. ${ }^{134}$ Think of the real estate market as an example, in which the sale price of a house depends in no small part on the sale price of similar homes in similar geographies.

As described above, patents are quite different from one another; they are bespoke rather than commoditized financial assets. There are conceivable patent market structures that could achieve commoditization, such as selling shares in a portfolio or in a holding company whose only asset is a patent. ${ }^{135}$ But because I want to remain neutral with respect to market structure, ${ }^{136}$ my use of the efficient capital markets hypothesis here must necessarily be qualified: It is a hypothetical ideal. The less an actual patent market resembles this ideal, the less informationally efficient it is likely to be. Because even informationally efficient patent markets are likely to incorporate some types of information more easily than others, less efficient markets will a fortiori exhibit the same characteristics. Pricing in most patent markets, then, will reflect estimates of the values of comparable patents. Because comparables are often easier to obtain for litigation outcomes than for commercialization outcomes, it is likely that litigation value will dominate.

I do not claim that this analysis will hold true in all circumstances. One variable that may affect pricing is the particular parties that comprise the

131. See, e.g., Colleen V. Chien, Predicting Patent Litigation, 90 TEX. L. REV. 283, 298 (2011). Indeed, this is the strategy that some defensive aggregators, such as RPX Corp., use to determine which patents to purchase on behalf of their clients. See RPX Corp., Defensive Aggregation, RPX RATIONAL PATENT, http://www.rpxcorp.com/rpx-services/rpx-defensivepatent-acquisitions/ (last visited Nov. 13, 2015).

132. Anne Kelley, Practicing in the Patent Marketplace, 78 U. CHI. L. REV. 115, 131 (2011).

133. See Ross ET AL., supra note 25, at 338; supra Part II; cf. Risch, Patent Portfolios, supra note 28 , at 104-05.

134. See Kelley, supra note 132, at 129-30.

135. See Risch, Patent Portfolios, supra note 28, at 102-03.

136. See supra Part II; Risch, Patent Portfolios, supra note 28, at 102-03. 
market. Gilson and Kraakman describe the roles that various intermediaries play in the securities markets. They argue that different institutions are equipped to handle different sorts of information costs. The rate of incorporation of information therefore depends not only on the nature of the information cost but also on the characteristics of the institutions that operate in the market. ${ }^{137}$ In patent markets, it is possible that even high cost information can be incorporated into the market price if the intermediaries are sufficiently able to process that information. Non-practicing entities in the current market, for example, are often praised for their ability to assess the value of patents. ${ }^{138}$ But they most often do so on the basis of litigation value, because their expertise lies in patent enforcement and their function is akin to providing litigation finance. ${ }^{139}$ But if the market becomes populated with operating companies that have expertise in commercialization, it stands to reason that they may make different assessments that feed into the market price.

A second variable is the possibility that developments in the law of patent damages might result in greater convergence between commercialization and litigation values. To the extent that the calculation of a "reasonable royalty" 140 more closely mirrors the economic contribution of the patent to an infringing device or process, then the litigation outcome should more closely mirror the commercialization outcome. ${ }^{141}$ But there will likely still be circumstances where, because of strategic behavior, the divergence in value is insurmountable. ${ }^{142}$

Ultimately, a liquid market that tends to price patents at their litigation value will tend to allocate those patents to parties who are more likely to realize that value through enforcement. There are reasons to think that

137. See Gilson \& Kraakman, Market Efficiency, supra note 127, at 613-21.

138. See, e.g., Osenga, supra note 32, at 452-53 ("Patent licensing companies, by virtue of their full-time status as intermediaries and repeat players in the market, are in a better postion to evaluate patents. Because of their repeat presence in the market, they gain specialization and experience in assessing patent value that individual inventors and small companies are generally unable to obtain.").

139. See Hagiu \& Yoffie, supra note 11, at 62; cf. Shyamkrishna Balganesh, Copyright Infringement Markets, 113 ColUM. L. REV. 2277, 2286 (2013) (defending copyright markets on litigation finance grounds).

140. 35 U.S.C. $\S 283$ (2015).

141. See, e.g., Daralyn J. Durie \& Mark A. Lemley, A Structured Approach to Calculating Reasonable Royalties, 14 LEWIS \& CLARK L. REV. 627, 642 (2010); Golden, supra note 112, at 508-09; Jorge L. Contreras \& Richard J. Gilbert, A Unified Framework for RAND and Other Reasonable Royalties 6-7 (Univ. of Utah Coll. of Law, Research Paper No. 91, 2015), http://ssrn.com/abstract=2502066.

142. See Lemley \& Shapiro, Patent Holdup, supra note 109, at 2008-09. 
allocation is suboptimal from the perspective of social welfare. Direct consumer welfare benefits come from commercialization, from bringing new technologies to market. Patent litigation is not inherently suspect, and indeed is the vehicle through which the benefits of the right to exclude are realized. But "[w]hen a company commercializes technology that it invented independently and later faces a patent assertion," the resulting judgment or license "provides no direct benefit to consumers." ${ }^{143}$ Such assertions, moreover, increase commercializing entities' costs, leading some to argue that they are amount to a tax on innovation or to pure rent seeking. ${ }^{144}$ Similarly, I do not mean to suggest that litigation or commercialization value is the "correct" price of a patent. ${ }^{145}$ The economic value of a patent is generally understood to be the difference between the value of the patented technology and the next best alternative, assuming a free choice between the two. ${ }^{146}$ The litigation value is likely to diverge farther from the economic value. This means that in a liquid market, a patent is likely to be an inefficient asset-it may fail to reflect the underlying value of the technology.

Notwithstanding the discussion above, I make no attempt to resolve here the question whether commercialization or litigation is more socially useful or reflect more clearly the economic value of a patent. My point here is more limited: the operation of a liquid patent market could bring about a particular allocation of patents among the actors in the market that results in a very different patent system from that which we currently enjoy. It means a shift from a system in which the right to exclude is allocated to the inventor to a system where the right to exclude is allocated to the highest bidder, who may then be incentivized to realize that value through enforcement. The implications of this system are complex. Suffice it to say that allocating patent rights solely through operation of the price system

143. See FTC REPORT, supra note 12 , at 52.

144. See id. at 53; Collen Chien, Startups and Patent Trolls, 17 STAN. TECH. L. REV. 461, 465 (2014). The magnitude of this tax may be significant. See, e.g., James Bessen \& Michael J. Meurer, The Direct Costs from NPE Disputes, 99 CORNELL L. REV. 387, 416 (2014). And there is little evidence that ex post patent assertions lead to real technology transfer. See Feldman \& Lemley, supra note 122.

145. Indeed, as Gilson and Kraakman explain, the efficient capital markets hypothesis was never meant to conflate informational efficiency with "fundamental efficiency." Properly understood, the hypothesis says nothing about whether markets will achieve correct pricing. See Gilson \& Kraakman, After the Financial Crisis, supra note 125, at 321-26.

146. See Contreras \& Gilbert, supra note 141, at 12-14, 35; Durie \& Lemley, supra note 141 , at 637 ; $c f$. Gilson \& Kraakman, After the Financial Crisis, supra note 125 , at 322-23 (fundamental value of a security is discounted cash flow). 
may bring about a host of socially undesirable results. ${ }^{147}$ At the very least, we need to think through whether and how such a system would continue to satisfy our normative priors.

\section{B. Allocating the Risks of Innovation}

The second function of capital markets is to allocate risk, and here too the analogy yields mixed results when applied to patent markets. There are two kinds of risk that a liquid market could help to mitigate. The first is the "market risk" associated with innovative activity, and the second is "infringement risk" associated with others' patenting. A liquid market for patents could in theory allow inventors to relieve themselves of the risk of commercialization or litigation, while simultaneously allowing potential infringers to bargain for an efficient allocation of litigation risk. But it is also possible that liquid patent markets could create more risk rather than less, either by drawing into the system patents that otherwise would be rationally under-enforced, or by skewing inventive activity towards patentability. Both of these effects occur because of the same inefficiencies in pricing discussed in the previous part. This leads to a conclusion that has been recognized elsewhere with respect to other markets: a liquid market for an inefficient asset may wind up producing more of the asset.

\section{Reducing Market and Infringement Risk}

Innovators face two different kinds of risks arising from their activities. The first is the risk associated with invention writ large. Invention is highly uncertain. Most inventions fail to become marketable products. ${ }^{148}$ So while it is true that a patent provides an incentive to invent insofar as it mitigates the risk of misappropriation of one's invention by others who can copy it, the patent does nothing to mitigate ordinary market risk. The vast majority of inventors earn little to no return on their investment simply because there is no one else willing to license or develop the invention protected by the patent. This is so, by the way, across the spectrum of inventors, from

147. See Amy Kapczynski, The Cost of Price: Why and How to Get Beyond Intellectual Property Internalism, 59 UCLA L. REV. 970, 984 (2012).

148. See Sichelman, supra note 50, at 362-64, 362 n.121 (aggregating and reporting survey data and other metrics that suggest "that less, probably much less, than half of all patented product inventions are commercialized"). 
individuals to startup companies to established enterprises. Much of corporate R\&D fails as well. ${ }^{149}$

Relatedly, even if there is economic value to a patent, inventors often cannot themselves capture that value through litigation. Litigation, of course, is costly, time consuming, and uncertain. ${ }^{150}$ Many inventors lack the funds or ability to bring infringement actions. And even those who do may find the decision to invest in litigation to have negative net present value. The ability to sell a patent into a liquid market potentially helps to cure these defects.

Most straightforwardly, because a liquid market could lower search and information costs, as described above, ${ }^{151}$ there is a better chance that patent holders who are not themselves in a position to commercialize or to litigate are more likely to find a partner who is. A liquid market might also, though, create more opportunities for patent holders to sell. There are a number of reasons why willing buyers might offer money in return for patents that cannot otherwise be monetized in the hands of their original inventors. It might be that a buyer with an existing portfolio will value a patent that is complementary to its existing holdings differently than a sole patent holder. ${ }^{152}$ Other sources of liquidity might base their business models expressly on risk management. Mhyrvold sometimes describes Intellectual Ventures in these terms. ${ }^{153}$ One of the benefits of a portfolio strategy is that it diversifies the cash flow returns from a large number of patents. ${ }^{154}$ The value of the portfolio is less dependent on the cash flows from any particular patent. And given that most patents are valueless, ${ }^{155}$ portfolios' performance is dependent largely on particularly valuable outlier patents. It is a rational strategy in this model to invest small sums of money in a large number of patents, most of which will fail to produce revenue, but a small

149. See id.

150. Patent litigation even more so. In 2011, the average cost of a patent lawsuit from complaint to judgment was about six million dollars per side. See AM. INTELLECTUAL PROP. LAW ASS'N, 2011 REPORT OF THE ECONOMIC SURVEY, at I-151-56 (2011), http://www.aipla.org/learningcenter/library/books/econsurvey/2011/Pages/Table-of-

Contents.aspx.

151. See ARORA ET AL., supra note 99, at 116; FABOZZI ET AL., supra note 8, at 6; Gans \& Stern supra note 101; supra Section II.A.1.

152. See Parchomovsky \& Wagner, supra note 74, at 32-37.

153. See Myhrvold, supra note 4 ("What we're really trying to do is create a capital market for inventions akin to the venture capital market that supports start-ups and the private equity market that revitalizes inefficient companies.").

154. See Parchomovsky \& Wagner, supra note 74, at 37-41.

155. See, e.g., John R. Allison et al., Valuable Patents, 92 GEO. L.J. 435, 440-41 (2004). 
number of which will produce outsized returns. ${ }^{156}$ Entities that engage in this strategy therefore tend to be lower cost risk bearers than individuals or undiversified operating companies.

Furnishing inventors with an option to sell, in addition to the options to commercialize and litigate, ${ }^{157}$ thus reduces each individual inventor's risk with respect to the likely cash flows from her patent. ${ }^{158}$ This in turn arguably furnishes additional incentive to invent. ${ }^{159}$ If inventors have greater assurance that they can achieve a return on their investment in inventive activity, they are more likely to undertake that activity. Because providing an incentive to invent is one of the core justifications for the patent system, ${ }^{160}$ liquid patent markets may be normatively desirable.

Along similar lines, a number of scholars have written about how patents can promote specialization in the innovation value chain. ${ }^{161}$ Arora and Merges, for example, argue that patents "make it possible for technologyintensive inputs to be supplied by separate firms" through the process of market exchange. ${ }^{162}$ "This, in turn, contributes to the viability of these specialized firms as standalone entities." 163 It stands to reason that improving the efficiency of exchange transactions through a liquid market lowers the transaction costs associated with specialization, and may contribute to easier specialization. ${ }^{164}$ And there is some historical evidence that, in fact, liquid secondary markets contributed to the growth of specialized "invention firms." 165 To the extent that specialization promotes efficiency in innovation - and to the extent that we believe smaller firms to

156. See Myhrvold, supra note 4 ("A single invention is typically very risky. However, if you build (as my company has) a diversified portfolio of tens of thousands of inventions that span a wide range of technologies, the aggregate risk becomes quite manageable.").

157. See supra notes 108-14 and accompanying text.

158. One common complaint about current patent markets is that they function primarily to monetize patents for creditors when patent-heavy firms go bankrupt. See, e.g., FTC REPORT, supra note 12, at 70. But see Risch, supra note 19, at 489-90 (finding that most NPE patents are not obtained in bankruptcy transactions). Providing a backstop for bankrupt firms is another way to reduce risks; I do not attempt to compare the welfare effects of providing this backstop prior to bankruptcy.

159. See Khan, supra note 32; Spulber, supra note 95, at 5.

160. See supra notes $39-45$ and accompanying text.

161. See, e.g., Ashish Arora \& Robert P. Merges, Specialized Supply Firms, Property Rights, and Firm Boundaries, 13 INDUS. \& CORP. CHANGE 451, 542 (2004).

162. Id. at 452 .

163. Id.; see also Barnett, supra note 51, at 790-93; Oren Bar-Gill \& Gideon Parchomovsky, Law and the Boundries of Technolog-Intensive Firms, 157 U. PA. L. REV. 1649, 1658-72 (2009).

164. See Myhrvold, supra note 4.

165. See Khan, supra note 32 , at 832-35. 
be more dynamic and innovative - then liquid patent markets may help to promote innovation through this mechanism as well. ${ }^{166}$

The second kind of risk arising from patents is infringement risk. Patents are "probabilistic."167 They are of uncertain validity and uncertain boundaries. As to the former, although patents enjoy a presumption of validity when they issue, ${ }^{168}$ validity is not conclusively established until patents are tested in litigation. Empirical evidence suggests that this uncertainty is significant-some studies find that upwards of $45 \%$ of patents litigated to final judgment are found to be invalid. ${ }^{169}$ The scope of even valid patents is also highly uncertain, and subject to the vagaries of claim construction, arguably the most contentious and difficult to predict aspects of patent litigation. ${ }^{170}$

This uncertainty means that an issued patent presents a risk of infringement to those working in the same field as the patent. Patents purport to cordon off a range of activities that persons are not supposed to engage in without a license from the patentholder. ${ }^{171}$ But because it is not clear either that those persons in fact cannot engage in the subject matter of the patent (i.e. that the patent is valid) or that those persons' activities are in fact within the exclusive right protected by the patent (i.e. that the boundaries are clear), it is very difficult to plan innovative investments. Often, innovative activity can be chilled by the mere presence of a patent, even if it is more likely than not that the activity can proceed. ${ }^{172}$ This is especially true in view of the fact that investments in innovation need to be made over time, with the result of that innovation itself uncertain at the end of the investment period.

A liquid patent market might help mitigate this uncertainty by allowing the market for patents to clear. In a market where pricing is determined in

166. But see infra Section II.B.2 (questioning whether liquid patent markets will produce more innovation or more patents).

167. See Lemley \& Shapiro, Probabilistic Patents, supra note 24, at 76.

168. 35 U.S.C. $\$ 282$ (a) (2015) ("A patent shall be presumed valid.").

169. See John R. Allison et al., Our Divided Patent System, 82 U. CHI. L. REv. 1073, 1099 (2015).

170. See, e.g., J. Jonas Anderson \& Peter S. Menell, Informal Deference: A Historical, Empirical, and Normative Analysis of Patent Claim Construction, 108 Nw. U.L. REV. 1, 4 (2013).

171. See Mark A. Lemley, The Regulatory Turn in IP, 36 HARV. J.L. \& PUB. POL'Y 109, 110 (2013) (describing a patent as a "regulatory intervention in the marketplace that is designed to restrict what people can do with their own ideas and their own property").

172. See Michael J. Burstein, Rethinking Standing in Patent Challenges, 83 GEO. WASH. L. REV. 498, 532-33 (2015); Christopher R. Leslie, The Anticompetitive Effect of Unenforced Invalid Patents, 91 MINN. L. REV. 101, 115-117 (2006). 
no small part by litigation value, ${ }^{173}$ entities can assess their exposure and, if it makes economic sense, mitigate their risk of infringement by buying the patent at the market clearing price rather than relying upon the vagaries of litigation. ${ }^{174}$ Some defensive aggregators adopt this strategy as a business model. ${ }^{175}$ Their clients invest in a fund that the aggregator uses to buy patents that pose a risk to the clients; the value proposition to clients is that the aggregator therefore clears infringement risk at a lower cost than in litigation. ${ }^{176}$ (And, from the perspective of the patent owner, this market provides a far easier way to enforce her patent).

One objection to this purported benefit is that perhaps we do not want the market for invalid patents to clear. Transactions over exclusive rights that ought not to have issued in the first place are socially wasteful. Merges, for example, writes, "[t]he market for patents unrelated to innovation adds nothing to overall social welfare." ${ }^{\prime 177} \mathrm{He}$ analogizes invalid patents to the market for blackmail. ${ }^{178}$ In such a market, the person who has damaging information and the person against whom the information may be used both benefit from a voluntary transaction in which the blackmailer gets paid, and the blackmailee does not suffer reputational harm. But it can hardly be said to improve social welfare. So too, the patent holder is made better off in a market transaction for her patent, and the potential infringer may buy patent peace at a lower price than the cost of litigation. But it is not clear this transaction is welfare enhancing.

The answer to this objection lies in weighing the cost of clearing the market for bad patents against the cost of reducing the prevalence of bad patents in the first instance. The United States Patent and Trademark Office ("PTO") received almost 600,000 patent applications in 2013, and issued over 300,000 patents. ${ }^{179}$ There is no reason to believe that these numbers will decline any time soon. At that volume, it is extremely costly for the PTO to ensure that every issued patent is valid. Indeed, Mark Lemley has long argued that the PTO is "rationally ignorant" in applying a relatively light screen to patent applications. ${ }^{180}$ This is because most patents are never

173. See supra Section II.A.2.

174. See Lemley \& Myhrvold, supra note 6, at 258.

175. Hagiu \& Yoffie, supra note 11 , at 56-58.

176. See, e.g., id.

177. Merges, supra note 34 , at 1603.

178. See id. at $1588,1600-01$.

179. See U.S. Patent \& Trademark OfFICE, Performance \& ACCOUNTABILITY RePort 143 (2014), http://www.uspto.gov/about/stratplan/ar/USPTOFY2014PAR.pdf.

180. See Mark A. Lemley, Rational Ignorance at the Patent Office, 95 Nw. U. L. REV. 1495,1497 (2001). 
the subject of litigation or licensing, so pose little social cost other than the cost of prosecution. ${ }^{181}$ Those patents which prove valuable enough to assert are then adjudicated more closely in litigation. ${ }^{182}$

As patent litigation, particularly as practiced by patent assertion entities, has grown, one of the common refrains has been to tighten standards at the PTO, to ensure that it issues fewer invalid or overbroad patents. ${ }^{183}$ Congress has also authorized a set of administrative procedures in the PTO-_."inter parties review" and "post grant review"-that appear to be viable avenues for challenging the validity of issued patents at a lower cost than through litigation. But the market solution described above may prove less socially costly. In other words, it might be the case that the market can clear bad patents at a lower overall social cost than PTO reform aimed at ensuring more rigorous examination of every patent. If the patent market clears risk at a market clearing price, then perhaps we do not have to worry about an oversupply of bad patents. The optimal solution to the problem of bad patents, of course, depends on the magnitude (and distribution) of the relative social costs.

\section{Increasing Systemic Risk}

It is also possible, however, that liquid patent markets could create more risk rather than less. There are two ways this could occur: First, the market could draw into the system patents that otherwise would have gone unenforced. Second, the market can encourage the production of more patents and, potentially, lower quality patents. The overall social welfare calculus depends on whether the benefits of risk reduction described above outweigh the costs of risk creation discussed below.

To begin, consider the flip side of Lemley's "rational ignorance" argument. The logic of tolerating a light screen at the PTO depends upon rational under-enforcement. ${ }^{184}$ That is, it is rational to allow litigation to screen invalid patents rather than administrative processes only when it remains true that relatively few patents are asserted. If patent assertions

181. Id.

182. See id. at 1501-03; see also David Fagundes \& Jonathan S. Masur, Costly Intellectual Property, 65 VAND. L. REV. 677, 693-704 (2012).

183. See, e.g., R. Polk Wagner, Understanding Patent-Quality Mechanisms, 157 U. PA. L. REV. 2135, 2139-45 (2009).

184. See Rebecca S. Eisenberg, Patent Costs and Unlicensed Use of Patented Inventions, 78 U. CHI. L. REV. 53, 62 (2011). 
begin to rise, then the social cost of invalid patents rises relative to the cost of screening out those patents.

Enter liquid markets. One potential effect of increasing liquidity is simply that more patents are now the subject of transactions than previously. As described above, the welfare effects of drawing more patents into the system this way are ambiguous. Of perhaps somewhat greater concern, more patents could wind up in litigation than in the absence of a liquid market. As described in Section II.A, when the fit between patents and technologies is imperfect, a liquid market may favor allocating patents based on their litigation value, and to those who are more likely to choose enforcement over commercialization or other options. ${ }^{185}$ This means that patents traded on the market may disproportionately come to be held by entities who choose to realize the asset's predicted cash flows through litigation. The result, in turn, may be more patent litigation rather than less.

More troublingly, a liquid patent market would likely impact the primary behavior of innovators, skewing inventive activity toward patentability. There are a couple of ways in which this could be problematic. For one thing, inventors may find it more cost effective to rely on patent protection to appropriate the gains from their R\&D investments than other less socially costly mechanisms for securing a return. Society could then be getting the same amount of innovation at a higher social cost. Alternatively, the attractiveness of securing a return on patentable inventions by selling the underlying patent into a liquid market could induce inventors to shift their activities toward things that are patentable rather than not, even where the latter may be more socially valuable. ${ }^{186}$ This is a variation of the familiar argument that stronger patents rights yield not more innovation, but more patents. ${ }^{187}$ Greater liquidity may, in some circumstances, generate more patents rather than more innovation.

How might this occur? Intuitively, the ability to monetize patents easily by selling them into a liquid market may lure more inventors to file more patents with a more secure expectation of garnering a return. More specifically, in the option calculation described above, ${ }^{188}$ a sale option is

185. See supra notes $135-38$ and accompanying text.

186. See Amy Kapczynski \& Talha Syed, The Continuum of Excludability and the Limits of Patents, 122 YALE L.J. 1900, 1943-44 (2013).

187. See, e.g., Bronwyn H. Hall \& Dietmar Harhoff, Recent Research on the Economics of Patents, 4 ANN. REV. ECON. 541, 547 (2012); Mariko Sakakibara \& Lee G. Branstetter, Do Stronger Patents Induce More Innovation? Evidence From the 1988 Japanese Patent Law Reforms, 32 RAND J. ECON. 77, 78 (2001); Josh Lerner, 150 Years of Patent Protection, 92 AM. ECON. REV. 221, 221 ( 2002).

188. See supra notes $175-77$ and accompanying text. 
likely to dominate the litigation and commercialization options because it is vastly more certain.

But there is a deeper problem with which the financial economics literature is familiar: moral hazard. Consider the growth of a secondary market for securities and derivatives of subprime mortgage loans in the mid-aughts. In this market, originators of mortgage loans- the banks that lent the initial capital to potential homeowners with poor credit-often packaged and sold financial instruments based on the underlying loans to third parties. When the extent of credit risk represented by those instruments became apparent, and the underlying mortgage loans began to default with greater frequency, this secondary market collapsed and the holders of the securities and derivatives faced significant losses when they were unable to liquidate their holdings for nearly the amount they paid. ${ }^{189}$

The "dominant" explanation for the growth, and eventual collapse, of the subprime mortgage market is the "originate to distribute" theory. ${ }^{190}$ Prior to the mid-2000s, most mortgage financing followed an "originate to hold" model, in which mortgage lenders held at least some substantial portion of the loans they issued for the duration of those loans. ${ }^{191}$ This was especially true for subprime loans, which generally could not be sold to the government-sponsored entities Fannie Mae and Freddie Mac. The development of a secondary market for subprime mortgages changed this dynamic, and the originators' business model increasingly shifted from one in which they kept their subprime loans on their own books to one in which they sold the loans in the secondary market to third-party buyers. ${ }^{192}$ The moral hazard arose because originators, no longer residual claimants to the securities they packaged and sold, had no incentive to keep up their underwriting standards. They could originate highly risky loans because, once sold, they were no longer exposed to that risk. As a result, the quality of underwriting went down, and more and more risky loans entered the market. ${ }^{193}$ To be sure, this explanation for the financial crisis is not without

189. See Gilson \& Kraakman, After the Financial Crisis, supra note 125, at 333-38.

190. Gary B. GoRTON, SLAPPEd By the INVISABle HAND: THE PANIC OF 2007 136-38 (2010).

191. Amiyatosh Purnanandam, Originate-to-Distribute Model and the Subprime Mortgage Crisis, REV. FIN. STUD. 1881, 1881-82 (2010), http://rfs.oxfordjournals.org/content/24/6/1881.full.pdf.

192. See id. at 1899-90; see also RoBert POzEN, Too BIG to SAVE? How to FIX THE U.S. FINANCIAL SYSTEM 18 (2009).

193. See Purnanandam, supra note 191, at 1897. 
its critics. ${ }^{194}$ But there is good empirical evidence to support the link between moral hazard and declining underwriting standards. ${ }^{195}$

This dynamic maps well onto the participants in liquid patent markets. When inventors are active participants in ongoing innovation, they often face infringement risk commensurate with the risk they themselves generate. That is, practicing entities that produce patents may, by virtue of practicing in the relevant art, expose themselves to a risk of infringing others' patents. ${ }^{196}$ While it is true that every patent holder has an incentive to draft her patent as broadly as possible, inventors who are exposed to symmetric risk have a countervailing incentive to monitor patent quality. This may be so at the retail level, wherein patentees will try to file applications that they are reasonably sure are valid and cover a range of technologies in order both to maximize their own chance of recovery and to have a strong counter-patent to use if they are sued. And it can also be true at the wholesale level. Witness attempts by many software companies to reform the law governing software patents.

If inventors can sell patents into a market in which they are no longer active participants - in which they no longer themselves have an interest in commercializing, or in which they no longer themselves face a symmetric risk of infringement liability from others-then their incentive is not to monitor patent quality. It is instead to put plausible patents into the market without regard to whether they are sure bets either in commercialization or in litigation. Indeed, to the extent that a liquid patent market aids in the formation of a completely distinct "invention" sector, ${ }^{197}$ participants in that sector will likely face incentives to generate and sell patents at a rapid clip. After all, that is the primary source of revenue generation in the business

194. See, e.g., GoRTON, supra note 190, at 144; Geetesh Bhardwaj \& Rajdeep Sengupta, Subprime Loan Quality 2-4 (Fed. Res. Bank of St. Louis, Working Paper 2008-036E, 2011). Interestingly, the leading alternative theory holds that the more significant problem was not moral hazard, but asymmetric information that prevented the purchasers of subprime mortgagebacked securities from fully understanding what they had bought. As discussed supra, this problem is even more pronounced with respect to liquid patents because patents are likely to be harder to value than subprime mortgages. Supra notes 117-26 and accompanying text.

195. See Benjamin J. Keys et al., Did Securitization Lead to Lax Screening? Evidence from Subprime Loans, 125 Q.J. ECON. 307, 309-13 (2010); Purnanandam, supra note 191, at 1897; Gary Gorton \& Andrew Metrick, Securitization 33-38 (Nat'1 Bureau of Econ. Research, Working Paper No. 18611, 2012) (reviewing literature).

196. See Chien, supra note 144 , at $472-73$. This dynamic has been similarly cited as a reason why the patent assertion entity business model succeeds. Because such entities do not themselves practice any inventions that might subject them to a risk of suit, they are immune to potential countersuits by their infringement defendants. The resulting asymmetry in litigation cost compels a higher rate of settlement. See id.

197. See supra notes $165-68$ and accompanying text. 
model. The result could be more and lower quality patents. This may expand rather than reduce the overall level of risk in the patent system.

\section{IMPLICATIONS AND CONCLUSIONS}

Applying the logic of financial economics to the patent system yields ambiguous results, at least as a matter of theory. Patent markets could lower search costs and generate pricing information that leads to more efficient transactions in technology, which everyone agrees is of great importance in fostering innovation up and down the supply chain. But where the fit between patents and technologies is imperfect, the patent becomes an inefficient unit of exchange and a liquid market could lead to significant strategic behavior. And while patent markets may help reduce both market risk and infringement risk to innovators, the financial economics literature tells us that a liquid market for an inefficient asset could simply result in the production of more of that asset.

Broadening the lens, this result should not be surprising. There are times when we think markets work well to allocate resources, and times when we think they do not. Stock markets, despite their flaws, generally do a good job allocating capital and diversifying risk. But we tend not to rely on markets to allocate other kinds of goods, particularly when we are concerned with distributive effects and moral hazard. The purchase and sale of human organs, for instance, is banned almost worldwide. And for good reason. It is commonly thought that, left to its own devices, a market for kidneys would crowd out altruistic donation, decrease supply, and increase prices with severe consequences for poor recipients, or would result in coercion of poor sellers with no reasonable economic alternative. ${ }^{198}$

By now I have, perhaps overwhelmingly, analogized a hypothetical patent market to markets for stocks, ${ }^{199}$ real estate, ${ }^{200}$ vintage jeans, ${ }^{201}$ subprime mortgages, ${ }^{202}$ and kidneys. ${ }^{203}$ There is good reason to invoke all of these disparate markets: the patent market might look like one or all of them, depending on factors that are likely to be context-specific. It is well understood that the patent system, though nominally unitary, in fact often

198. See, e.g., I. Glenn Cohen, Transplant Tourism: The Ethics and Regulation of International Markets for Organs, 41 J.L. MED. \& ETHICs 269, 273-74 (2013).

199. See supra notes $73,137-39$ and accompanying text.

200. See supra notes 133-34 and accompanying text.

201. See supra note 79 and accompanying text.

202. See supra notes $190-96$ and accompanying text.

203. See supra note 198 and accompanying text. 
functions differently in different technological and business contexts. ${ }^{204}$ As the discussion above demonstrates, the same is likely to be true of patent markets. The operation of patent markets will be industry- and technologyspecific. It will depend on the fit between patents and technologies, on the characteristics, economics, and business plans of the sources of liquidity and potential sellers in any given sub-market, and on the legal environment as well. Determining with any certainty whether a liquid patent market is socially useful in a particular context requires empirical research into the factors listed above and others. This Essay therefore cannot be predictive. I seek instead to open an agenda for research into the workings of nascent patent markets and their evolution, using the theoretical discussion herein as a framework and a guide.

The demonstrable need for a more nuanced understanding of patent markets calls into question the seemingly common assumption that patent markets are socially useful and that the only relevant policy question remains how to improve their function. It also puts the lie to the argument that if only we could make patent markets more robust and liquid, then the market would cure all that ails the patent system. It may be that the ongoing "financialization" of the patent system is useful in some contexts, but it cannot be a panacea for the problems that the patent system faces. In real terms, two conclusions follow. First, we should continue to make reforms to the patent system that are unambiguously useful and that may improve the operation of markets as well. Improving the notice function of patents is one such reform. But, second, we should not give up on reforms outside the context of markets in the hope that they will prove unnecessary. This is especially true with respect to patent quality. It is not clear that a market will eliminate bad patents at low social costs, and there is reason to think that the opposite result may in fact occur. Patent reform aimed at lowering the number of invalid patents or at better aligning the substantive standards of patent law to the innovation market failures it is supposed to correct will remain critically important.

204. See DaN L. Burk \& MARK A. Lemley, The PATENT CRISIS AND How the COURTS CAN SOLVE IT 49 (2009); Allison et al., supra note 155. 